\title{
PENERAPAN KESEHATAN KESELAMATAN KERJA DALAM MANAJEMEN PELAKSANAAN PROYEK KONSTRUKSI DI PEMBANGUNAN GEDUNG RUMAH SAKIT
}

\author{
Sri Kiswati ${ }^{1}$ \\ Universitas Bina Sarana Informatika \\ Email : sri.srk@bsi.ac.id \\ Ummi Chasanah² \\ Program Studi DIII Teknik Sipil Fakultas Teknik Universitas Pandanaran \\ Jl. Banjarsari Barat No. 1 Tembalang Semarang 50275 \\ Email : chasanah_ummi01@yahoo.co.id*
}

\begin{abstract}
ABSTRAK
Penerapan kesadaran Kesehatan dan Keselamatan Kerja (K3) banyak menyita perhatian berbagai organisasi segala bidang, karena mencakup permasalahan segi prikemanusiaan, biaya dan manfaat ekonomi, aspek hukum, pertanggung jawaban serta citra organisasi itu sendiri. Proses pembangunan proyek konstruksi umumnya merupakan kegiatan yang mengandung unsur bahaya, sehingga hal kesehatan dan keselamatan Kerja perlu diperhatikan dan di kelola secara khusus. Dalam pelaksanaan konstruksi sering kali K3 kurang diperhatikan oleh pekerja. Kesadaran penerapan tertib K3 pada Pelaksanaan Konstruksi sudah berjalan cukup baik dengan adanya jaminan sosial tenaga kerja (Jamsostek) bagi para pekerja proyek yang merupakan perhatian yang diberikan perusahaan kepada para pekerja yang sesuai dengan aturan yang berlaku. Walaupun secara teknis masih terdapat beberapa kekurangan. Diantaranya belum tersedianya tenaga profesional dibidang K3, sifat pekerja lebih memilih tidak menggunakan Alat Pelindung Diri dan lebih memilih bekerja berdasarkan pengalaman dan mengabaikan K3, tidak adanya pelatihan khusus mengenai K3 kepada para pekerja serta tidak adanya pengawasan langsung dari pihak pemerintah terhadap pelaksanaan K3 dilokasi pelaksanaan pembangunan. Proyek konstruksi memiliki sifat yang khas, diantaranya adalah tempat kerjanya di ruang terbuka yang dipengaruhi cuaca, jangka waktu pekerjaan terbatas, menggunakan pekerja dengan berbagai macam karakterdan terkadang pekerja kurang peduli, kurang sadar akan pentingnya K3.
\end{abstract}

Kata kunci : Penerapan K3, Manajemen Pelaksanaan, Konstruksi, Rumah Sakit

\section{PENDAHULUAN Latar Belakang}

Proyek konstruksi di Indonesia ini yang mengalami kecelakaan kerja, terutama konstruksi yang berada di ketinggian lebih dari 3 lantai. Kecelakaan kerja yang dapat juga mengakibatkan luka ringan, sedang maupun berat bahkan dapat berujung dengan kematian. Kecelakaan kerja tersebut dapat berakibat cacat yang permanen. Dari kecelakaan yang terjadi tersebut ada yang mengakibatkan kematian, cacat permanen atau pekerja tidak mampu melakukan pekerjaannya lagi.

Sehingga kecelakaan kerja yang menyebabkan penderitaan bagi korban dan keluarga korban. Akibat dari kecelakan kerja yang mengakibatkan cacat permanen bahkan kematian, maka keluarga korban akan mengalami perubahan ekonomi pula. Untuk itu pengertian dari kecelakaan kerja adalah suatu kejadian yang tidak diduga dari semula dan tidak dikehendaki yang mengganggu suatu proses dari aktivitas yang telah dibuat dari semula dan dapat mengakibatkan kerugian baik korban manusia maupun harta benda.

Sedangkan pengertian dari kesehatan dan keselamatan kerja adalah segala daya upaya maupun pemikiran yang ada dan ditujukan untuk menjamin keutuhan dan kesempumaan baik jasmaniah maupun rohaniah dari tenaga kerja yang sedang melaksanakan pekerjaan. Kesehatan dan keselamatan kerja sangat perlu ditingkatkan 
untuk meningkatkan kesejahteraan tenaga kerja menuju masyarakat adil dan makmur dari pekerjanya.

Kerugian yang diakibatkan karena kecelakaan dalam bentuk material dapat berupa kehilangan uang dan kerusakan harta benda maupun kehilangan dalam bentuk waktu kerja. Oleh karena itu pencegahan kecelakaan kerja adalah merupakan hal yang penting, baik dilihat dari sesi ekonomi maupun dan sesi kemanusiaan. Setiap manusia pada dasamya tidak ada yang ingin rnengalami kecelakaan kerja terhadap dirinya maupun terhadap segala harta benda yang dimilikinya. Sehingga keinginan untuk mendapatkan perlindungan maupun jaminan keamanan terhadap dirinya, dan harta bendanya. Semua kecelakaan kerja, baik langsung maupun tidak langsung dianggap berasal dan kegagalan manusia.

\section{Perumusan}

Dengan uraian seperti tersebut di atas, maka yang perlu di bahas adalah pentingnya penerapan kesehatan keselamatan kerja pada setiap pelaksanaan konstruksi.

\section{Pembatasan masalah}

Penelitian ini di batasi pada pentingnya kesehatan keselamatan kerja untuk setiap pelaksanaan konstruksi secara umum di Indonesia.

\section{Tujuan Penelitian}

Penelitihan ini bertujuan sebagai berikut :

1. Untuk meningkatkan kesadaran semua pihak akan pentingnya K3di setiap pelaksanaan konstruksi.

2. Untuk mengantisipasi kecelakaan kerja yang kemungkinan terjadi, karena kecelakaan kerja dapat berakibat fatal bagi tenaga kerjanya.

\section{LANDASAN TEORI}

\section{Kesehatan}

Kesehatan kerja merupakan salah satu bagian dari keselamatan kerja maupun Occupational Safety and Health (OSH). Kesehatan kerja dengan tujuan agar para pekerja nyaman, terhindar dari kecelakaan, sehat, produktif, dan mampu berdaya saing serta berkembang secara berkesinambungan tidak terganggu dari kecelakaan. Kesehatan kerja harus terjaga, terpelihara, dan ditingkatkan oleh upaya Kesehatan Kerja. (Kurniawidjaja, 2010)

Penyelenggaran kesehatan kerja dapat berupa :

a. Sarana, tenaga, dan organisasi.

b. Pelaksanaan pemeriksaan kesehatan kerja tenaga kerja secara rutin, berkala, khusus, dan purna bakti.

c. Pelaksanaan P3K (petugas, kotak, da nisi kotak P3K).

d. Pelaksanaan gizi kerja

e. Pelaksanaan pemeriksaan syarat-syarat ergonomi.

f. Pelaksanaan pelaporan

Kesehatan kerja merupakan hal yang sangat penting untuk di jaga dan terjaga demi kelangsungan, kelancaran dari proses pelaksanaan konstruksi.

Keselamatan kerja merupakan keadaan di mana pekerja maupun tenaga kerja merasa aman, nyaman, di tempat lingkungan kerja dan faktorfaktor yang berpengaruh dapat menunjang kualitas kerja.

\section{Keselamatan Kerja}

Keselamatan kerja adalah hal yang perlu diperhatikan di dalam pengelolaan manajemen konstruksi. Keselamatan kerja terhadap situasi dan kondisi kerja sangat berpengaruh pada prestasi kerja dan pada akhirnya terhadap biaya kerja. Seperti Negara yang sedang berkembang maupun ynag tengah berkembang, mengenai keselamatan kerja sangat ditekankan dan dicantumkan dalam rencana anggaran biaya di kontrak kerja.

Keselamatan kerja sangat berpengaruh terhadap kinerja dan keberlangsungan dari proyek maupun industri konstruksi. Abai terhadap keselamatan kerja akan mengakibatkan ketidaknyamanan pekerja dan tingkat kecelakaan kerja yang tinggi pula. Pekerjaan konstruksi yang menerapkan disiplin dalam K3 akan berpengaruh baik terhadap tenaga kerja dan pelaksanaan pekerjaan konstruksi. Perlindungan bagi tenaga kerja merupakan penerapan perencanaan K3 dari hal utama perlindungan tenaga kerja, sehingga proses pelaksanaan pekerjaan konstruksi dapat berjalan dengan baik dan lancar.

Penerapan K3 dalam perencanaan industri konstruksi sekarang ini diwajibkan untuk dianggarkan dan diwajibkan untuk dilaksanakan 
di industri konstruksi manapun. Keselamatan kerja akan menjadi lebih efektif lagi, jika adanya keterlibatan komitmen manajemen terlibat nyata dari pekerja yang menanganinya. Keterlibatan pekerja keselamatan kerja dapat dilakukan antara lain keaktifan pekerja dalam kegiatan $\mathrm{K} 3$, memberikan masukan mengenai pentingnya $\mathrm{K} 3$ dan kondisi yang membahayakan jika melalaikan K3, menjalankan dan melaksanakan K3 sesuai aturan, serta memberikan masukan mengenai prosedur kerja yang aman dengan terus menerapkan K3 (Ramli, 2010).

\section{Perundang-Undangan Kesehatan dan Keselamatan Kerja (K3)}

Di Indonesia telah ada Undang-Undang kerja dan Undang-Undang kecelakaan. Menurut Dilly, 2011, mengatakan bahwa kesehatan dan keselamatan kerja merupakan Undang-Undang No.1 tahun 1970 tentang keselamatan kerja yang diundangkan. Undang-Undang tersebut mengganti Veiligheids Reglement tahun 1910, dan tahun 1073 telah berdiri Ikatan Higienen Perusahaan, kesehatan dan keselamatan kerja.

Berikut merupakan beberapa pekerjaan yang perlu ijin khusus, karena pekerjaan yang jarang dilakukan antara lain : bekerja di ruang terbatas, menggunakan bahan kimia berbahaya, menggunakan bahan yang mudah terbakar, menggunakan bahan yang mudah meledak, bekerja yang berhubungan dengan arus listrik, pasang skafolding, bekerja dengan cara menyelam, memindahkan benda berat, bekerja di luar jam normal, penggalian, pembongkaran, dan bekerja di ketinggian. (Buku Saku, 2019).

\section{Manajemen Kesehatan dan Keselamatan Kerja}

Menurut Austen dan Neale, 1991, Kesehatan dan keselamatan kerja merupakan hal yang sangat penting dan perlu kesadaran semua pihak pelaku industry konstruksi.

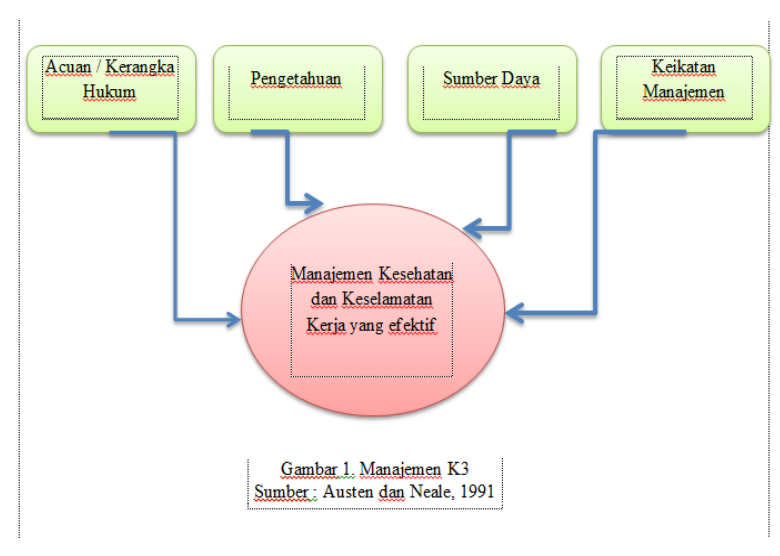

\section{Metodologi Penelitian}

Penelitian ini dilakukan pada proyek konstruksi secara umum, dengan menggunakan sampling responden. Analisa penelitian ini bersifat deskriptif, yang menggambarkan keadaan objek secara kualitatif tanpa adanya pengujian hipotesisnya. Responden pada penelitian ini di ambil dari responden yang expect di bidang K3.

K3 dapat di audit secara internal dalam meningkatkan organisasi $\mathrm{K} 3$ di setiap perusahaan dengan penanggung jawab audit mempunyai wewenang penuh terhadap fungsi pengawasan dan pemeriksaan. Audit harus diverifikasi oleh konsultan penerbit yang bersertifikasi OHSAS 18001-1999 secara berkala dan dapat dicabut jika terjadi pelanggaran. (Abrar Hussein, 2011).

Kecelakaan kerja dalam UU No.1 tahun 1970 yang dimaksud tempat kerja adalah tiap ruangan baik itu bertutup maupun terbuka, bergerak atau tertutup. Sehingga kecelakaan kerja yang merupakan kecelakaan yang menimpa pekerja harus di antisipasi dengan mentaati peraturan-peraturan K3 yang berlaku. (Ervianto, 2005).

Potensi sumber bahaya antara lain adalah :pekerja tertimbun longsoran tanah, pekerja tenggelam air banjir, pekerja tersengat aliran listrik, menghirup gas beracun, tersembur zat kimia, menghirup debu, pekerja tertimpa alat berat, digigit inatang berbisa, terkena ledakan, dan pekerja terjatuh ke dalam galian.(LP2K3L-A2K4).

Penelitian ini dilaksanakan melalui observasi/pengamatan di lapangan, melakukan studi kepustakaan, analisis, dan kesimpulan. 


\section{Bagai Alir}

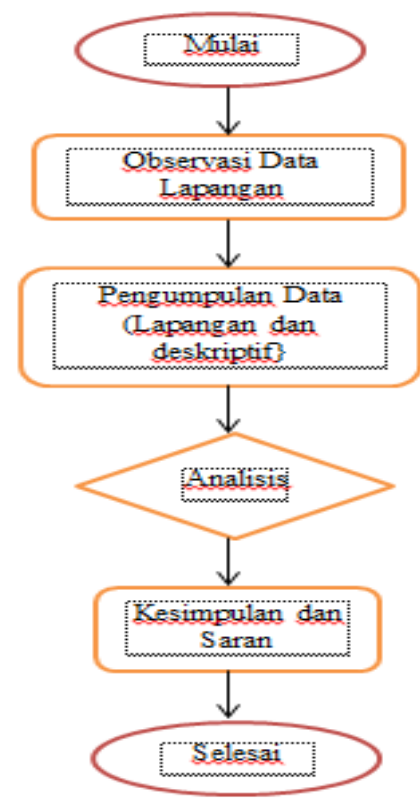

Gambar 1.2 Bagan Alir Pelaksanaan

\section{PEMBAHASAN}

Penelitian dari observasi ini didasarkan pada penerapan K3 untuk pembangunan gedung gedung bertingkat. Penerapan K3 sangat penting untuk diterapkan, hal ini dikarenakan kelalaian penerapan K3 dapat berakibat fatal, jika sampai terjadi kecelakaan. Untuk mengantisipasi berbagai kecelakaan yang mungkin terjadi pada setiap pelaksanaan kegiatan mulai dari K3 terendah sampai dengan penerapan K3 yang sesuai. Pada pelaksanaan $\mathrm{K} 3$ yang paling sederhana mulai dari penggunaan APD diantaranya : helmet, safety shoes, safety glasses, earplug, masker mulut, sarung tangan, safety belt, dan jaket pelampung.

Menurut Ferraro, 2002, dasar dari kebiasaan keselamatan ini merupakan sikap dari persepsi pekerja terhadap keselamatan kerja, sehingga merupakan gambaran perilaku pekerja terhadap pelaksanaan peraturan K3 sebagai pengendali potensi bahaya.

Menurut Ramli, 2010 keterlibatan pekerja dalam keselamatan kerja dapat dilakukan dengan berbagai cara, diantaranya keaktifan pekerja dalam kegiatan K3, memberikan masukan adanya bahaya di lingkungan kerja, menjalankan dan melaksanakan K3 secara aman.

Penerapan K3 pada Pelaksanaan Konstruksi
Penerapan K3 untuk pelaksanaan konstruksi pada bangunan gedung, baik itu gedung sederhana maupun gedung tidak sederhana. Dalam PP K3 No. 52 Tahun 2018. Penerapan K3 diwajibkan di setiap proyek, dengan besaran $1 \%$ s/d 1,5\% dari nilai proyek yang di peroleh. Dari hasil sampling responden yang di peroleh, terangkum bahwa penerapan K3 sudah cukup baik dilaksanakan, walaupun masih terdapat kekurangan, namun dari sisi safety pekerja proyek telah menggunakan Alat Pelindung Diri dengan baik. Berdasarkan data dari sampling responden terhadap pengamatan di pelaksanaan proyek secara umum telah melaksanakan penerapan K3. Terangkum dari hasil responden tersebut adalah sebagai berikut :

- 1 : setuju dilaksanakan

- 2 : tidak setuju dilaksanakan

- 3 : kurang setuju dilaksanakan

- 4 : kadang-kadang dilaksanakan

Terlihat dalam tabel hasil sampling responden adalah sebagai berikut :

\begin{tabular}{|c|c|c|c|c|}
\hline $\mathrm{No}$ & Uramanpererrapan Kis secan unum & Kateronoi & \multicolumn{2}{|c|}{ Viliai } \\
\hline & & & & 34 \\
\hline 1 & Sygarad unum Kij Jang alssandan & 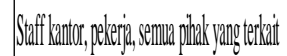 & & \\
\hline 2 & 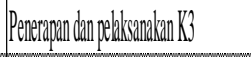 & 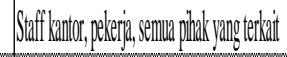 & 1 & \\
\hline & 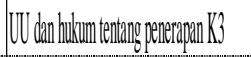 & Stafiflantor & $v$ & \\
\hline & Manajemen Ki & Stafl lantor & & 1 \\
\hline$j$ & Peadsananan dan noersisonal K3 & Stafif lantor & & 1 \\
\hline & 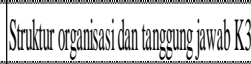 & 3 Stafl lantor & & \\
\hline & 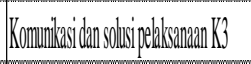 & Stafif lantor & & 1 \\
\hline & 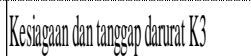 & Staffl kantor dan pekeria & & \\
\hline & Timalan Ki & Stafil lantor & & \\
\hline & Auld pererapan K3 & Staff lantortor & & 1 \\
\hline & DokmentasisiK3 & Staff lantion & $\sqrt{1}$ & \\
\hline
\end{tabular}

Sumber : observasi data

Penerapan penggunaan peralatan $\mathrm{K} 3$ secara umum yang sering dilakukan saat pelaksanaan pembangunan antara lain sebagai berikut : 


\begin{tabular}{|c|c|c|c|c|c|c|}
\hline \multirow{3}{*}{ No. } & \multirow{3}{*}{ Uraian pekerjaan } & \multicolumn{4}{|c|}{ K3 } & \multirow{3}{*}{ Keterangan } \\
\hline & & \multicolumn{2}{|c|}{ APD yang tersedia } & \multicolumn{2}{|c|}{$\begin{array}{c}\text { APD yang digunakan } \\
\text { pekerja }\end{array}$} & \\
\hline & & $\mathrm{Ya}$ & Tidak & Ya & Tidak & \\
\hline \multicolumn{7}{|c|}{ 1) Pekerjaan Tanah } \\
\hline & a Sepatu nenoaman & $\sqrt{1}$ & & $\sqrt{1}$ & & Tersedia \\
\hline & & $\sqrt{1}$ & & 1 & & Tercedin \\
\hline & U Darulig tallgall & $v$ & & $r$ & & Iersecula \\
\hline & c Masker pelindung & & $\sqrt{ }$ & & $\sqrt{ }$ & Tidak terseia \\
\hline & d Helm pelindung & & $\sqrt{ }$ & & $\sqrt{ }$ & Tidak terseia \\
\hline & e Pelindung mata & & $\sqrt{ }$ & & $\sqrt{ }$ & Tidak terseia \\
\hline & f Pelindung telinga & & $\sqrt{ }$ & & $\sqrt{ }$ & Tidak terseia \\
\hline & g Jaket / rompi pelindung & & $\sqrt{ }$ & & $\sqrt{ }$ & Tidak terseia \\
\hline & h Sabuk / tali pengaman & & $\sqrt{ }$ & & $\sqrt{ }$ & Tidak terseia \\
\hline & & & & & & \\
\hline \multicolumn{7}{|c|}{2 Pekerjaan pondasi dan struktur } \\
\hline & a Sepatu pengaman & $\sqrt{ }$ & & $\sqrt{ }$ & & Tersedia \\
\hline & b Sarung tangan & $\sqrt{ }$ & & $\sqrt{ }$ & & Tersedia \\
\hline & c Masker pelindung & & $\sqrt{ }$ & & $\sqrt{ }$ & Tidak terseia \\
\hline & d Helm pelindung & & $\sqrt{ }$ & & $\sqrt{ }$ & Tidak terseia \\
\hline & e Pelindung mata & & $\sqrt{ }$ & & $\sqrt{ }$ & Tidak terseia \\
\hline & f Pelindung telinga & & $\sqrt{ }$ & & $\sqrt{ }$ & Tidak terseia \\
\hline & g Jaket / rompi pelindung & & $\sqrt{ }$ & & $\sqrt{ }$ & Tidak terseia \\
\hline & h Sabuk / tali pengaman & & $\sqrt{ }$ & & $\sqrt{ }$ & Tidak terseia \\
\hline \multicolumn{7}{|c|}{3 Pekerjaan pengelasan } \\
\hline & a Sepatu pengaman & $\sqrt{ }$ & & $\sqrt{ }$ & & Tersedia \\
\hline & b Sarung tangan & $\sqrt{ }$ & & $\sqrt{ }$ & & Tersedia \\
\hline & c Masker pelindung & $\sqrt{ }$ & & $\sqrt{ }$ & & Tersedia \\
\hline & d Helm pelindung & $\sqrt{ }$ & & & $\sqrt{ }$ & Tersedia \\
\hline & e Pelindung mata & & $\sqrt{ }$ & $\sqrt{ }$ & & Tidak terseia \\
\hline & f Pelindung telinga & & $\sqrt{ }$ & $\sqrt{ }$ & & Tidak terseia \\
\hline & g Jaket / rompi pelindung & & $\sqrt{ }$ & & $\sqrt{ }$ & Tidak terseia \\
\hline & h Sabuk / tali pengaman & & $\sqrt{ }$ & & $\sqrt{ }$ & Tidak terseia \\
\hline & & & & & & \\
\hline \multicolumn{7}{|c|}{4 Pekerjaan dengan ketinggian } \\
\hline & a Sepatu pengaman & $\sqrt{ }$ & & $\sqrt{ }$ & & Tersedia \\
\hline & b Sarung tangan & $\sqrt{ }$ & & $\sqrt{ }$ & & Tersedia \\
\hline & c Masker pelindung & $\sqrt{ }$ & & & $\sqrt{ }$ & Tersedia \\
\hline & d Helm pelindung & $\sqrt{ }$ & & $\sqrt{ }$ & & Tersedia \\
\hline & e Pelindung mata & $\sqrt{ }$ & & $\sqrt{ }$ & & Tersedia \\
\hline & f Pelindung telinga & $\sqrt{ }$ & & & $\sqrt{ }$ & Tersedia \\
\hline & g Jaket / rompi pelindung & $\sqrt{ }$ & & & $\sqrt{ }$ & Tersedia \\
\hline & h Sabuk / tali pengaman & $\sqrt{ }$ & & $\sqrt{ }$ & & Tersedia \\
\hline & & & & & & \\
\hline \multicolumn{7}{|c|}{5 Pemakaian alat berat } \\
\hline & a Sepatu pengaman & & $\sqrt{ }$ & & $\sqrt{ }$ & Tidak terseia \\
\hline & b Sarung tangan & & $\sqrt{ }$ & & $\sqrt{ }$ & Tidak terseia \\
\hline & c Masker pelindung & & $\sqrt{1}$ & & $\sqrt{ }$ & Tidak terseia \\
\hline & d Helm pelindung & $\sqrt{1}$ & & $\sqrt{1}$ & & Tersedia \\
\hline & e Pelindung mata & & $\sqrt{ }$ & & $\sqrt{ }$ & Tidak terseia \\
\hline & f Pelindung telinga & & $\sqrt{ }$ & & $\sqrt{ }$ & Tidak terseia \\
\hline & g Jaket / rompi pelindung & $\sqrt{ }$ & & & & Tersedia \\
\hline & h Sabuk / tali pengaman & & $\sqrt{ }$ & & $\sqrt{ }$ & Tidak terseia \\
\hline
\end{tabular}

Berdasarkan survey, pengamatan di beberapa kegiatan pembangunan, ternyata sebagian besar para pekerja telah menyadari pentingnya $\mathrm{K} 3$. Walaupun $\mathrm{K} 3$ yang tersedia dan yang digunakan masih sebatas Alat Pelindung Diri yang sederhana. Dan masih ada sebagian dari pekerja yang kurang memperhatikan pentingnya K3 dirinya.

\section{Sikap Pekerja di Pelaksanaan}

Dari data yang diperoleh, dari pengamatan yang dilakukan masih terlihat kurang adanya kesadaran pekerja terhadap pentingnya penerapan K3. Selain itu masih banyak yang menganggap bahwa penggunaan K3 itu tidak penting, walaupun K3 telah diwajibkan. Sikap meremehkan K3 dapat berakibat fatal, karena salah satu faktor kecelakaan kerja adalah penggunaan $\mathrm{K} 3$ yang tidak tertib. Beberapa faktor yang dapat menyebabkan kecelakaan kerja maupun penyakit kerja antara lain :

1. Pekerja tidak terampil dalam penggunaan alat yang digunakan untuk bekerja.

2. Pekerja kurang berhati-hati, lalai, kurang sehat saat bekerja.

3. Tidak tersedia K3 dengan baik, sehingga pekerja tidak menggunakan K3.

4. Alat kerja yang digunakan sudah tidak layak pakai, sehingga membahayakan pekerja.

5. K3 yang tersedia tidak mencukupi jumlah pekerjanya.

Dari data maupun analisa di atas, diperoleh keterangan bahwa pekerjaan konstruksi menurut penyedia jasa dengan kondisi kebenaran di lokasi ternyata pekerja sudah dilengkapi dan menerapkan penggunaan APD, walaupun masih ada beberapa pekerja yang tidak tertib APD. Hal ini bukan menjadi indikator bahwa semua pekerja tidak menggunakan alat pelindung diri (APD). Perusahaan terkait pada dasarnya sudah melengkapi dan memberikan perlengkapan APD bagi pekerjanya.

\section{Pedoman Pencegahan Kecelakaan Kerja}

Dari uraian di atas, kecelakaan kerja selain mengakibatkan adanya korban, kerusakan, dan lain sebagainya. Jika kecelakan kerja itu dikarenakan alat maka akan berdampak pada lingkungan. Untuk menghindari kecelakaan tersebut, ada organisasi ketenagakerjaan internasional atau International Labour Organization (ILO) telah menyusun beberapa rekomendasi. Selain itu masing - masing Negara 
telah memiliki undang - undang dan peraturan tersendiri.

\section{Dampak dan Kompensasi Kecelakaan Kerja}

Kecelakaan kerja dapat berdampak pada kerugian bagi pekerja yang berupa cidera bahkan meningggal dunia. Akibat kecelakaan kerja tersebut, proses kelanjutan dari kegiatan sesaat juga terganggu, karena tidak bisa melanjutkan kegiatan untuk sementara waktu. Dalam pelaksanaan suatu proyek konstruksi K3 seharusnya sejak awal diterapkan. Anggaran K3 dalam proyek konstruksi sekarang wajib dianggarkan dan dilaksanakan, adapun besarnya anggaran adalah maksimal $1 \% \mathrm{x}$ biaya proyek yang disepakati.

Pekerja yang mengalami cidera baik itu sementara atau permanen, maka untuk sementara waktu akan terhenti dari kegiatan proyek. Sehingga pekerja tersebut mengalami hari-hari kerja yang tidak dapat dilakukan, atau dengan kata lain hari-hari kerja yang hilang atau mondays lost.

\section{KESIMPULAN}

Berdasarkan hasil analisa mengenai penerapan kesehatan dan keselamatan kerja, maka K3 wajib dianggarkan dan dilaksanakan maksimal $1 \% \mathrm{x}$ anggaran yang di sepakati. Adanya jaminan sosial tenaga kerja bagi pekerja konstruksi merupakan salah satu bentuk perhatian dari perusahaan kepada karyawannya. Penyediaan alat pelindung diri (APD) dari penyedia jasa kepada pekerja yang cukup memadai, namun terkadang masih ada pekerja yang lalai atau kurang peduliakan pentingnya APD tersebut.

\section{DAFTAR PUSTAKA}

Austin AD, Neale, 199, Manajemen Proyek Konstruksi, PT Pustaka Binaman Pressindo, Jakarta

Abrar Hussein, 2011, Manajemen Proyek, Perencanaan, Penjadwalan, dan Pengendalian Proyek, Andi, Yogyakarta

Dilly, Steven F., 2011, Penerapan Sistem Pengendalian K3 Pada Pelaksanaan Konstruksi, Fakultas Teknik Unsrat, Manado
Ervianto, Wulfram I, 2002, Manajemen Proyek Konstruksi, Edisi Revisi, Andi, Yogyakarta

Jasa Marga, Buku Saku, Pedoman untuk Pelaksanaan Keselamatan dan Kesehatan Kerja (K3) Konstruksi, 2019

Kurniawidjaja, L. Meily, 2010, Teori dan Aplikasi Kesehatan Kerja, UI, Press. Jakarta

LP2K3L-A2K4， 2019, Materi Pelatihan Lembaga Pendidikan dan Pelatihan Keselamatan, Kesehatan Kerja \& Lingkungan, Indonesia

Peraturan Pemerintah, No. 52, Tahun 2018, Tentang K3

Ramli.S, 2010, Sistem Manajemen Keselamatan dan Kesehatan Kerja OHSAS 18001, Jakarta, Dian Rakyat

Undang - Undang, No. 1, Tahun 1970, Tentang Keselamatan Kerja 